\title{
ISOLATION AND PURIFICATION OF QUEBRACHITOL FROM RUBBER FACTORY EFFLUENTS
}

\author{
AMNP Attanayake and PAJ Yapa \\ Department of Botany, University of Sil Jayewardenepura, Nugegoda
}

Sri Lanka has been producing about 70,000-90,000metric tons of factory effluents annually in rubber plantations. Most of this is discharged into environment with out any prior treatment, causing serious environmental pollution problems in rubber growing areas. Use of rubber factory effluents as a fertilizer for rubber and also for vegetable crops, has been investigated by several workers as an alternative to expensive trea ment methods. Recovery of non-rubber substances of economic importance from rubber factory effluents, has also been attempted.

Quebrachitol is the chief water-soluble compound among sugars that are present in rubber factory effluent. This non-rubber substance has a great demand in European countries due to its high pharmaceutical value. (as an antibiotic, anticanser drug etc) There are also several other potential applications related to quebrachitol, (i.e. in tacquer industry for the preparation of the resin, as a chiral starting material for organic chervical syntheses). It has also been used as a pharmacological research tool for the study of cell signaling mechanism and cellular responses. Since rubber serum is a waste product of the rubber industry and a good natural source for quebrachitol, isolation of quebrachitol from rubber factory effluent was attempted in this study. A column chromatographic method was adopted in this study to isolate quebrachitol from Hevea serum. Undiluted rubber serum obtained directly from the coagulating tank was used for isolation of quebrachitol. Rubber serum after conce ttration by evaporation was deionized by cation (Amberlite IR 120, $\mathrm{H}+$ form) and anion exchange (Dowex 1x8, formate form) column chromatography. Two methods were attempted for crystallization of quebrachitol from concentrated elute. Of them, alcohol precipitation method was found to be more efficient than cooling method. Precipitate was dissolved in water asd recrystallized with ethanol. Employing this method, $613.3 \mathrm{mg}$ of whitish quebrachitol crys a s (m.p. $193-195^{\circ} \mathrm{C}$ ), were obtained from one liter of rubber factory effluent.

The development of a method to isolate quebrachitcl from rubber factory effluent is of duel importance (i.e. whilst yielding a substance of high commercial importance, it also eliminates the need for costly treatment). With the high market value of this substance, quebrachitol can be a good foreign exchange earner for Sri Lanka. 